\title{
Article \\ Effects of Harvest Stage, Storage, and Preservation Technology on Postharvest Ornamental Value of Cut Peony (Paeonia lactiflora) Flowers
}

\author{
Jing Sun, Haixia Guo and Jun Tao *
}

check for updates

Citation: Sun, J.; Guo, H.; Tao, J. Effects of Harvest Stage, Storage, and Preservation Technology on Postharvest Ornamental Value of Cut Peony (Paeonia lactiflora) Flowers Agronomy 2022, 12, 230. https:// doi.org/10.3390/agronomy12020230 Academic Editor: Christine E.H. Coker

Received: 12 December 2021

Accepted: 16 January 2022

Published: 18 January 2022

Publisher's Note: MDPI stays neutral with regard to jurisdictional claims in published maps and institutional affiliations.

Copyright: (C) 2022 by the authors. Licensee MDPI, Basel, Switzerland. This article is an open access article distributed under the terms and conditions of the Creative Commons Attribution (CC BY) license (https:// creativecommons.org/licenses/by/ $4.0 /$ )
College of Horticulture and Plant Protection, Yangzhou University, Yangzhou 225009, China; jingsun@yzu.edu.cn (J.S.); ghxmz120201@163.com (H.G.)

* Correspondence: taojun@yzu.edu.cn; Tel.: +86-0514-8799-7219

\begin{abstract}
Herbaceous Peony has high ornamental value but short flowering period, which limits the development of the cut flower industrialization. We studied the effects of different harvest stages, pre-treatment solutions, storage methods, and preservation solutions, including different carbon sources on the ornamental of cut Paeonia lactiflora flowers. The results showed that the "Opentop type" peony had the highest flowering rate and longer vase life harvested at the soft-bud (SB) stage, and the "unfold-petal type" peony collected at the changing-color (CC) stage had the highest flowering rate and the best vase ornamental. In addition, the vase effect of cut peony pre-treated with 8-hydroxyquinoline (8-HQ) and nanosilver (NS) was better than that of the control, and the decline of related protective enzyme activity slowed down in the later stage of storage. The protective enzyme activity of cold storage and low oxygen (CS + LO) treated cut flowers was higher than that of cola storage (CS) treated cut flowers. Apparently, in the fresh-keeping solution containing glucose, sucrose, and trehalose, the flower diameter of cut flowers increased, and the vase life was prolonged, among which the increase of flower diameter treated with glucose was the most significant, and trehalose can delay flowering, increase flowering period, and delay aging.
\end{abstract}

Keywords: harvest stage; pre-treatment solution; storage; preservatives; sugar; morphological; physiological index

\section{Introduction}

Herbaceous peony (Paeonia lactiflora Pall.), known as a Chinese traditional famous flower, is a perennial herbaceous plant belonging to the genus Paeonia of Paeoniaceae. Owing to its characteristics of wide varieties, fascinating, and fragrant flowers, peony has become one of the most significant ornamental plants at home and abroad, with high economic and cultural value. In recent years, peony, as a novel cut flower, has become more and more popular in the international flower market [1]. However, the market-oriented development of cut peony is limited due to the concentration of the flowering period, shortage of storage and preservation technology. To maintain the development of the cut peony industry, it is necessary to develop a mechanism or procedure that can prolong the life of cut flowers while maintaining high ornamental quality during vase insertion.

Because of the different growth patterns of petals, there are two new morphological types of peony cut flowers. One is the unfold-petal type, in which petal extension and loosening start from the outer petal and develop from the outside to the inside. The other is the open-top type, in which the inner petal is extended before the bud opens, forming lacunae at the top of the bud, and the petals are folded inside [2].

The different development stage of unfold-petal type: (1) Tight-bud (TB) stage, the bud is obviously enlarged, but the bud body is hard, and the calyx is completely or nearly completely covered; (2) unfold-petal (UP) stage, the sepals stop growing, the petals exserted but dull in color; outermost 1-2 petals begin to loosen, but the bud is firm; (3) changing-color 
(CC) stage, several outer petals are loose, bright to normal color petals, bud is firm, slightly soft only at the top; (4) soft-bud (SB) stage, the outer petals begin to stretch, the upper part of the bud is obviously small, and the lower part of bud is firm; (5) initial-flowering (IF) stage, all the petals begin to spread, the buds are completely loose, and the flowers begin to express ornamental value. (6) Full-flowering (FF) stage, the petals are fully extended, and the variety, color, and shape characteristics are fully displayed. (7) Flower-wilting (FW) stage, the petals begin to fall off or wither, and the flowers gradually lose their ornamental value.

The different development stages of the open-top type: (1) tight-bud (TB) stage, with unfold-petal type; (2) open-top (OT) stage, the top of the bud is opened (the opening is about $1 / 3$ of the diameter of the bud), and the petals are exposed, but the bud is hard, and the petals are dark; (3) unfold-top (UT) stage, the bud top opening expanded to more than half of the bud diameter, obviously visible internal folding arrangement of the inner petals, bud top is soft, but the lower of bud is solid, the petals color is dark. (4) Soft-bud (SB) stage, the bud top burst expands to be equal to the bud diameter, the top part of the bud is soft until the whole bud is soft, the dew part is bright, close to the color when the flower is open. (5) (7) Initial-flowering flower-wilting stage, same unfold-petal type [2,3]. The vase life of cut flowers at different harvest stages was different. Cut flowers in tuberose (Polianthes tuberosa L.) harvested at the single floret opening stage (S2) had the longest vase life and the lowest physiological weight loss [4]. The natural vase life of peonies are about 5-6 days depending on the cultivar, flower harvest time, and plant growth environment $[5,6]$. Due to the variety of peony flower types, the opening effect of different varieties at the same level of harvesting is not consistent. Studies have shown that the vase life and the opening life of cut herbaceous peony flowers harvested at stage II (Unfold-petal stage) were longer than at stages IV (Soft-bud stage) [7]. It is key to guarantee the quality of cut peony after harvest to know the optimum harvest time of cut peony varieties.

The common way to prolong the economic feasibility of cut peony is to store it at low temperature after cutting. Low temperatures can control metabolism, reduce consumption of stored compounds and respiratory water loss, and limit the development of pathogens [8,9]. High humidity during storage is essential to avoid dryness, but the high humidity environment is a good medium for mold growth, impeding the absorption and transport of water in flowers, resulting in premature flower aging [10]. At the same time, the low-temperature storage time is limited (about 20-30 d on average), and the quality of the vase after storage is unstable [11]. Therefore, it is very important to create a new storage methods to improve the storage quality and vase ornamental of cut peony flowers. Controlled atmosphere storage (CA) is based on the common cold storage, which can effectively prolong the storage period of commodity by adjusting the CA components in the storage environment [12]. Under CA conditions, the reduction of oxygen availability may be considered suitable to reduce oxidation reaction, resulting in the reduction of enzyme browning [13]. CA is often used to preserve fruits and vegetables, but there are few reports on its application in the preservation of cut flowers.

In the industrial production of cut flowers, fungicides are often added to prevent or minimize the breeding of microorganisms, thus as to delay aging and increase the appreciation of cut flowers. For over half a century, the esters of 8-hydroxyquinoline have been used as potent biocides for cut flowers in mixtures with sucrose [14]. The effects on cut flowers have been demonstrated in D. caryophyllus [15], H. macrophylla [16], rose (Rosa hybrid) [17] and E. grandiflorum [18]. Another such biocide is nanosilver (NS). NS as a new nano material is considered to be a safe inorganic antibacterial material, and it has been widely used in the preservation area [19]. Moreover, the effect NS as a new fungicide on cut flowers were reported in R. hybrida [20], G. jamesonii [21], lily (Lilium spp.) [22] and D. Caryophyllus [23]. In our study, it was chosen to compare with the commonly used 8-HQ as two pre-treatment solutions and combined with CA storage to find a more suitable storage method for cut $P$. lactifora. 
Preservation technology is an important means to delay the aging of flowers and keep their good ornamental effect. Chemical preservation technology has been widely used and popular because of its low cost, convenient operation, and obvious fresh-keeping effects on flowers [24]. As one of the most commonly used chemical preservation technologies, chemical preservatives are used to control ethylene synthesis and microbial proliferation, maintain adequate water and respiratory balance and petal color, thus delaying the senescence of cut flowers and maintaining their ornamental value [25]. These solutions mainly consist of sugars, acidifiers, and fungicides, while other compounds may be added to induce antioxidant reactions $[25,26]$. Some studies have shown that the post-harvest quality and the vase life of cut flowers depend mainly on the carbohydrate consumption of petals [27]. Carbohydrate consumption can be addressed by supplementing exogenous sugars in the vase solution. The addition of sugar to vase solution increases the osmotic concentration of petal cell sap, provides a substrate for respiration and osmotic regulation of cut flowers, and maintains the dilatancy of cut flowers [28]. In addition, sugar is also thought to delay petal senescence by inhibiting ethylene synthesis [29]. In our paper, we compared the effect of adding different exogenous sugars to the fresh-keeping solution on petal senescence.

\section{Materials and Methods}

\subsection{Plant Material}

Cut P. lactiflora cv. 'Dan Feng' 'Lu Xihong' 'Qihua Lushu ang' 'Lian Tai' 'Hong Feng' flowers were screened from the germplasm bank of Horticulture and Plant Protection, Yangzhou University. Two “Open-top type" cut peony 'Dan Feng' and 'Lu Xihong' were harvested in the tight-bud (TB) stage, unfold-top (UT) stage, and soft-bud (SB) stage, respectively. Two "unfold-petal type" cut peony 'Qihua Lushuang' and 'Lian Tai' were, respectively, collected in the tight-bud (TB) stage, changing-color (CC) stage, and softbud (SB) stage. 'Hong Feng' was harvested in the soft-bud (SB) stage. According to Eason [29], all harvested cut flowers were free of obvious symptoms such as disease, pests, or mechanical defects. All cut flowers for the bottling test should be trimmed to $30 \mathrm{~cm}$ long with 1-2 compound leaves. All vase experiments were carried out in a post-harvest evaluation room at a temperature of $22-25^{\circ} \mathrm{C}$ and $40-60 \%$ relative humidity, and in the vase insertion experiment, the vase insertion solution was changed every 2 days. All samples were collected immediately after the morphological observation and placed in the $-80{ }^{\circ} \mathrm{C}$ refrigerator.

\subsection{Optimum Harvesting Period}

“Open-top type" cut P. lactiflora 'Dan Feng' 'Lu Xihong,' and “Unfold-petal type" cut P. lactiflora 'Qihua Lushuang' 'Lian Tai' harvested at different stages were chosen as the experimental material. The trimmed, cut flowers were inserted into a test tube containing $2 / 3$ deionized water, and there were 5 repeating vases for each cut peony in each harvesting period with 1 cut flower per vase.

\subsection{Combination of Pre-Treatment Solution and Storage Mode}

The cut P. lactiflora 'Qihua Lushuang' flowers were selected as the test materials. A total of 40 flower stems were immersed in pre-treatment solution 1:200 mg/mL 8-hq for $6 \mathrm{~h}$, and were divided into 2 groups to place in $2{ }^{\circ} \mathrm{C}$ cold storage for direct refrigeration (CS) and ultra-low oxygen refrigeration (CS + LO), with 20 flowers in each group. Another 40 flowers were sprayed with pre-treatment solution 2:30 ppm NS for $6 \mathrm{~h}$, and then divided into 2 groups, with 20 flowers in each group, and placed in $2{ }^{\circ} \mathrm{C}$ cold storage for direct refrigeration (CS) and ultra-low oxygen refrigeration (CS + LO). Hypoxic refrigeration was achieved by placing cut flowers in special air-filled bags filled with carbon dioxide and using a gas concentration detector to control the oxygen concentration to $5 \%$ and carbon dioxide concentration to $20 \%$. Cut flowers on the 1st and 30th days of storage were taken 
for the bottle insertion test, respectively, and each treatment has 10 vase repetitions with 1 flower per tube.

\subsection{Preservatives Containing Different Carbon Sources}

The variety of 'Hong Feng' was chosen as the test material. Four kinds of preservative solutions were prepared by adding $20 \mathrm{~g} / \mathrm{L}$ carbon sources (mannitol, glucose, sucrose, and trehalose) with deionized water as the control and $200 \mathrm{mg} / \mathrm{L} 8-\mathrm{HQ}+150 \mathrm{mg} / \mathrm{L}$ citric acid $+50 \mathrm{mg} / \mathrm{L} 6-\mathrm{BA}$ as the basic simulation. The cut peony flowers were inserted into the test tube for preservation. Each treatment had 20 tube replicates with 1 cut flower per vase.

\subsection{Morphological Indexes Measurements}

Vase life observation: when beginning the vase experiment, the appearance changes of cut $P$. lactiflora flowers were recorded every day, and the time that petal wilting and falling off occurred was recorded as the end of vase life.

The fresh weight and diameter of each flower were measured every day. The fresh weight of cut flowers was the average value of 5 flowers by electronic balance (T-500, Gandg Testing Instrument Factory, China), and the change rate of fresh weight (CRFW) was used to represent the difference of fresh weight between different treatments. $\mathrm{CRFW}=\left(\mathrm{FWn}-\mathrm{FW}_{0}\right) / \mathrm{FW}_{0} \times 100 \%$, where $\mathrm{FWn}$ is the fresh weight of cut flowers at day 1,2 , 3, etc., and $\mathrm{FW}_{0}$ is the fresh weight of cut flowers at day 0 . Cut flower diameter was measured with vernier caliper with the average of 2 cross measurements on each flower.

\subsection{Physiological Index Analysis}

Each index had 3 biological replicates. Petals of all samples were ground with liquid nitrogen. $1.0 \mathrm{~g}$ petal powder extract was extracted with $4 \mathrm{~mL} 0.1 \mathrm{~mol} / \mathrm{L}$ phosphate buffer $(\mathrm{PH}=7.0-7.4)$ or $9 \mathrm{~mL}$ normal saline, centrifuged at $4{ }^{\circ} \mathrm{C}$ for $10 \mathrm{~min}$. The separated supernatant was diluted to $5 \%$ of the concentration with phosphate buffer or saline solution. Then, the activities of superoxide dismutase (SOD), peroxidase (POD), catalase (CAT), and ascorbate peroxidase (APX) were evaluated according to the kit (Nanjing Jiancheng Institute of Biological Engineering, Nanjing, China).

\subsection{Statistical Analysis}

SPSS (IBM SPSS Statistics 26) was used for statistical analysis. One-way analysis of variance (ANOVA) was used to determine significant differences between treatments $(\alpha=0.05)$, followed by Duncan's post hoc test.

\section{Results}

\subsection{The Optimum Harvest Stage of Cut P. lactiflora}

Cut P. lactiflora 'Dan Feng' harvested in the SB stage had the highest flowering rate up to $100 \%$, a longer full blooming period, and the longest vase life of about 7.6 days. Moreover, it has better ornamental value. The cut flowers harvested at the UT stage have a lower flowering rate of $80 \%$ and bloom later, but they can still reach the level of full flowering and have a longer vase life of about 7.2 days. The flowering rate of 'Lu Xihong' harvested at the UT stage and SB stage was the same as $100 \%$. However, the full blooming time and vase life of cut flowers harvested in the UT stage was longer than that in the SB stage, about 7.2 days. Two cut flowers harvested in the TB stage both had a low flowering rate of only $40 \%$, short vase life of around 5-6 days, and poor ornamental quality (Table 1, Figure 1). 
Table 1. Effects of harvesting stage on flowering rate and vase life of "open-top type" cut P. lactiflora.

\begin{tabular}{cccc}
\hline Cultivar & Harvest Stage & Flowering Rate (\%) & Vase Life (Days) \\
\hline \multirow{2}{*}{ 'Dan Feng' } & TB (tight-bud) & $40 \%$ & $5.8 \pm 0.16^{\mathrm{a}}$ \\
& UT (unfold-top) & $80 \%$ & $7.2 \pm 0.14^{\mathrm{b}}$ \\
& SB (soft-bud) & $100 \%$ & $7.6 \pm 0.12^{\mathrm{c}}$ \\
\hline \multirow{2}{*}{ 'Lu Xihong' } & TB (tight-bud) & $80 \%$ & $6.1 \pm 0.12^{\mathrm{a}}$ \\
& UT (unfold-top) & $100 \%$ & $7.2 \pm 0.13^{\mathrm{b}}$ \\
& SB (soft-bud) & $100 \%$ & $6.8 \pm 0.10^{\mathrm{c}}$ \\
\hline
\end{tabular}

Note: Means followed by the different lower-case letters have a significant difference at $\alpha=0.05$ (Duncan's test).

(A)<smiles>[Te]C1CCCC1</smiles>

Day 1

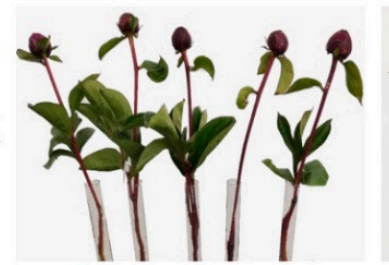

Day 3

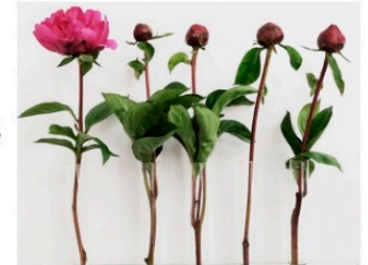

Day 6

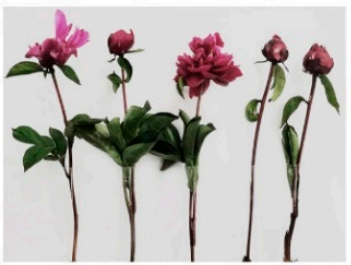

(B)

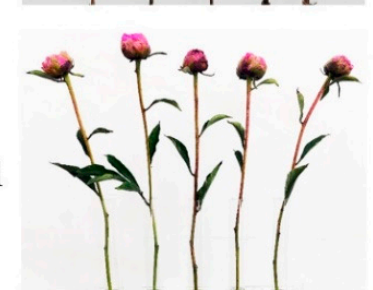

Day 1
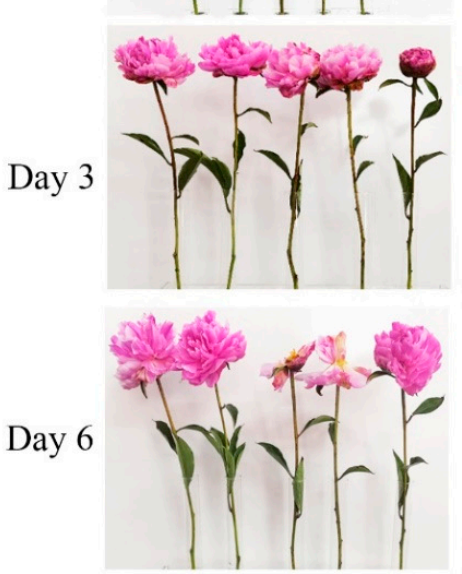

UT
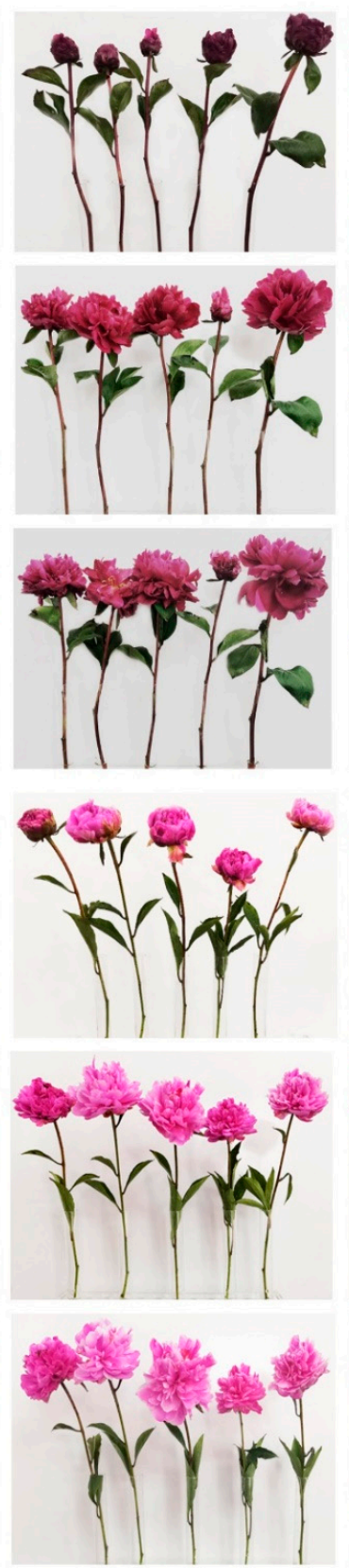

SB
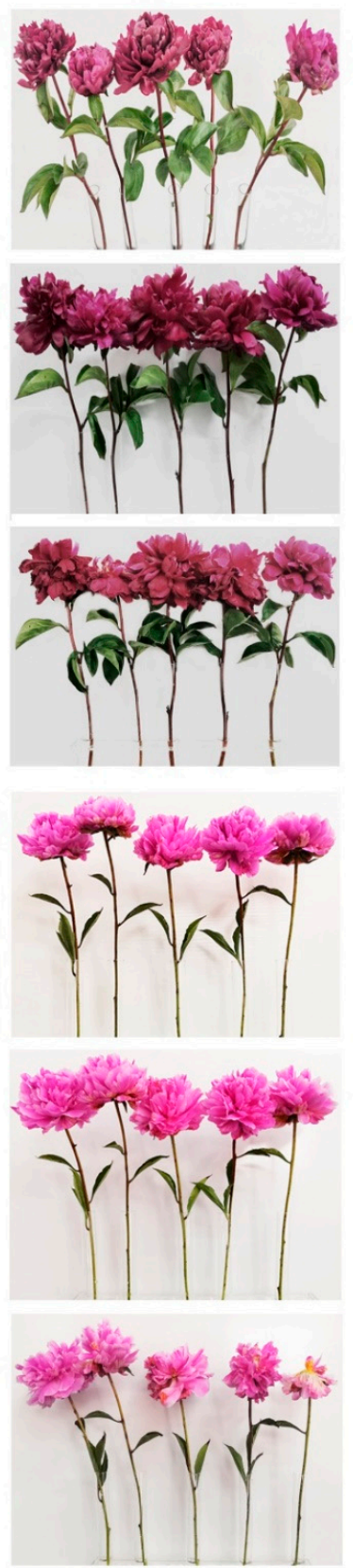

Figure 1. Flowering morphological of different harvest stages of "open-top type" cut P. lactiflora. (A) The appearance of flowering changes of 'Dan Feng' in three harvesting stages on the first, third, and sixth vase day. (B) The appearance of flowering morphology changes of 'Lu Xihong' in three harvesting stages on the first, third and sixth vase day. 
Both kinds of cut flowers reached their best flowering state on the third day after harvesting and were fully open. On the sixth day, some flowers dropped petals and began to decline (Figure 1). The maximum flower diameter of the two kinds of cut flowers harvested at the SB stage can be up to $11-13 \mathrm{~cm}$, which was larger than that of the cut flowers harvested at the TB and UT stage (Figure 2A,C). The change rate of fresh weight of the two cut flowers harvested at the UT stage dropped below zero at the latest and began to lose water at the last, followed by the SB stage, and the last is the TB stage (Figure 2B,D).
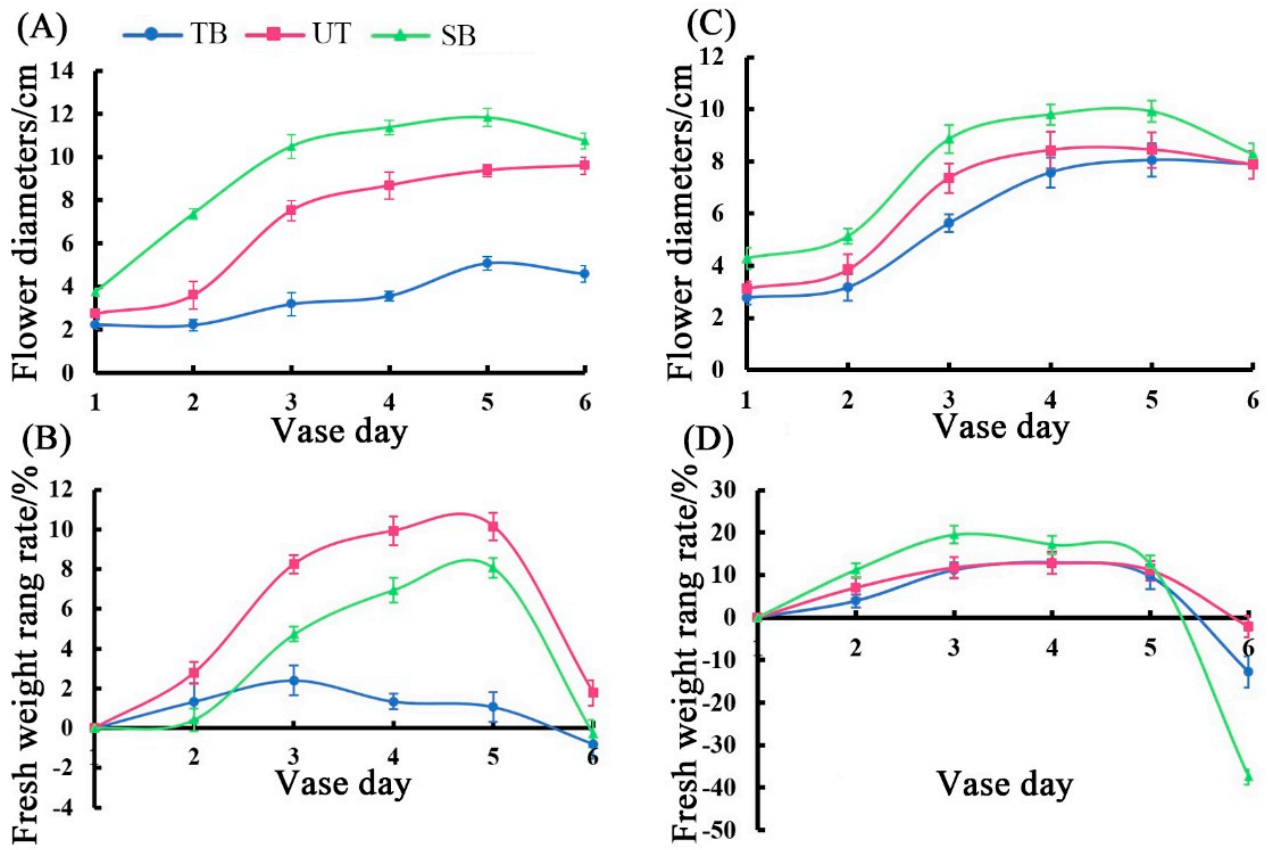

Figure 2. Flower physiological characteristics of in different harvest stages of "open-top type" cut P. lactiflora. (A,C) Flower diameter change and fresh weight change rate of 'Dan Feng' in three harvesting stages during vase. (B,D) Flower diameter change and fresh weight change rate of 'Lu Xihong' in three harvesting stages during vase. TB, tight-bud; UT, unfold-top; SB, soft-bud. Values are expressed as the mean \pm SD of triplicate assays. Vertical bars represent the standard deviations of the means.

Two "unfold-petal type" cut P. lactiflora harvested in the CC and SB stage had the highest flowering rate, up to 100\%. However, the cut flowers harvested at the CC stage, which had a longer blooming period and a longer vase life of 7.5 days than those harvested at the SB stage, have better ornamental value. The two cut flowers harvested in the TB stage had a lower flowering rate of $80 \%$ and a later flowering stage, but the bottle life could reach about 8 days, which was significantly higher than the cut flowers collected in the CC and SB stage (Table 2, Figure 3).

Table 2. Effects of harvesting stage on flowering rate and vase life of "unfold-petal type" cut P. lactiflora.

\begin{tabular}{cccc}
\hline Cultivar & Harvest Stage & Flowering Rate (\%) & Vase Life (Days) \\
\hline \multirow{3}{*}{ 'Qihua Lushuang' } & TB (Tight-bud) & $80 \%$ & $7.8 \pm 0.1^{\mathrm{a}}$ \\
& CC (Changing-color) & $100 \%$ & $7.5 \pm 0.12^{\mathrm{b}}$ \\
& SB (Soft-bud) & $100 \%$ & $7.0 \pm 0.19^{\mathrm{c}}$ \\
\hline \multirow{3}{*}{ 'Lian Tai' } & TB (Tight-bud) & $80 \%$ & $7.8 \pm 0.16^{\mathrm{a}}$ \\
& CC (Changing-color) & $100 \%$ & $7.6 \pm 0.19^{\mathrm{b}}$ \\
& SB (Soft-bud) & $100 \%$ & $7.2 \pm 0.09^{\mathrm{c}}$ \\
\hline
\end{tabular}

Note: Means followed by the different lower-case letters have a significant difference at $\alpha=0.05$ (Duncan's test). 
(A)

TB

$\mathrm{CC}$

SB

Day 1
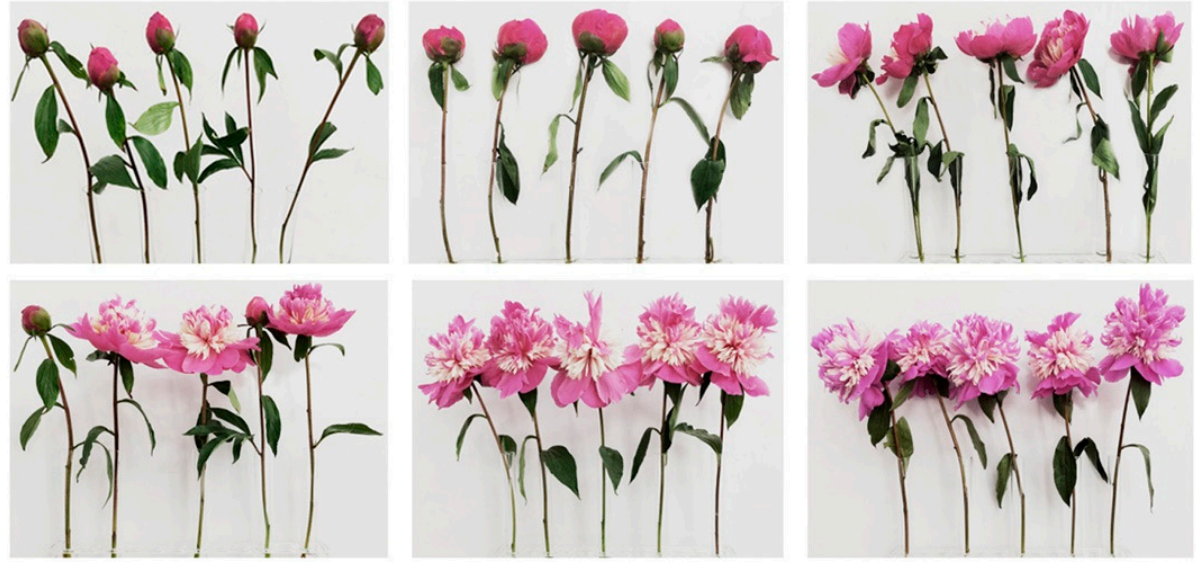

Day 3
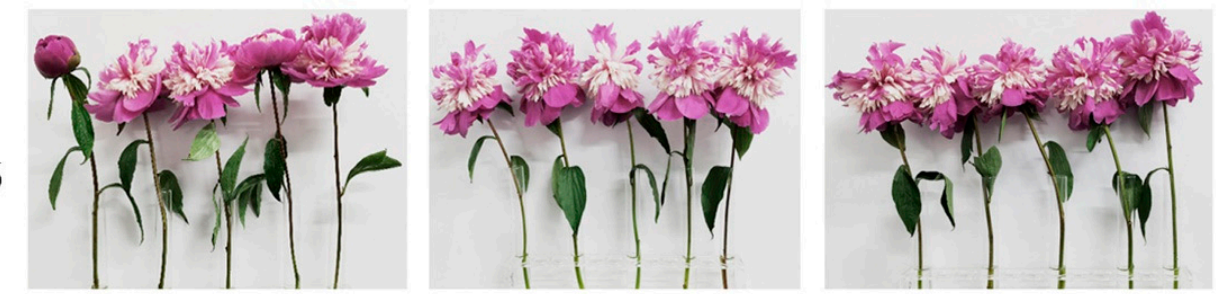

(B)
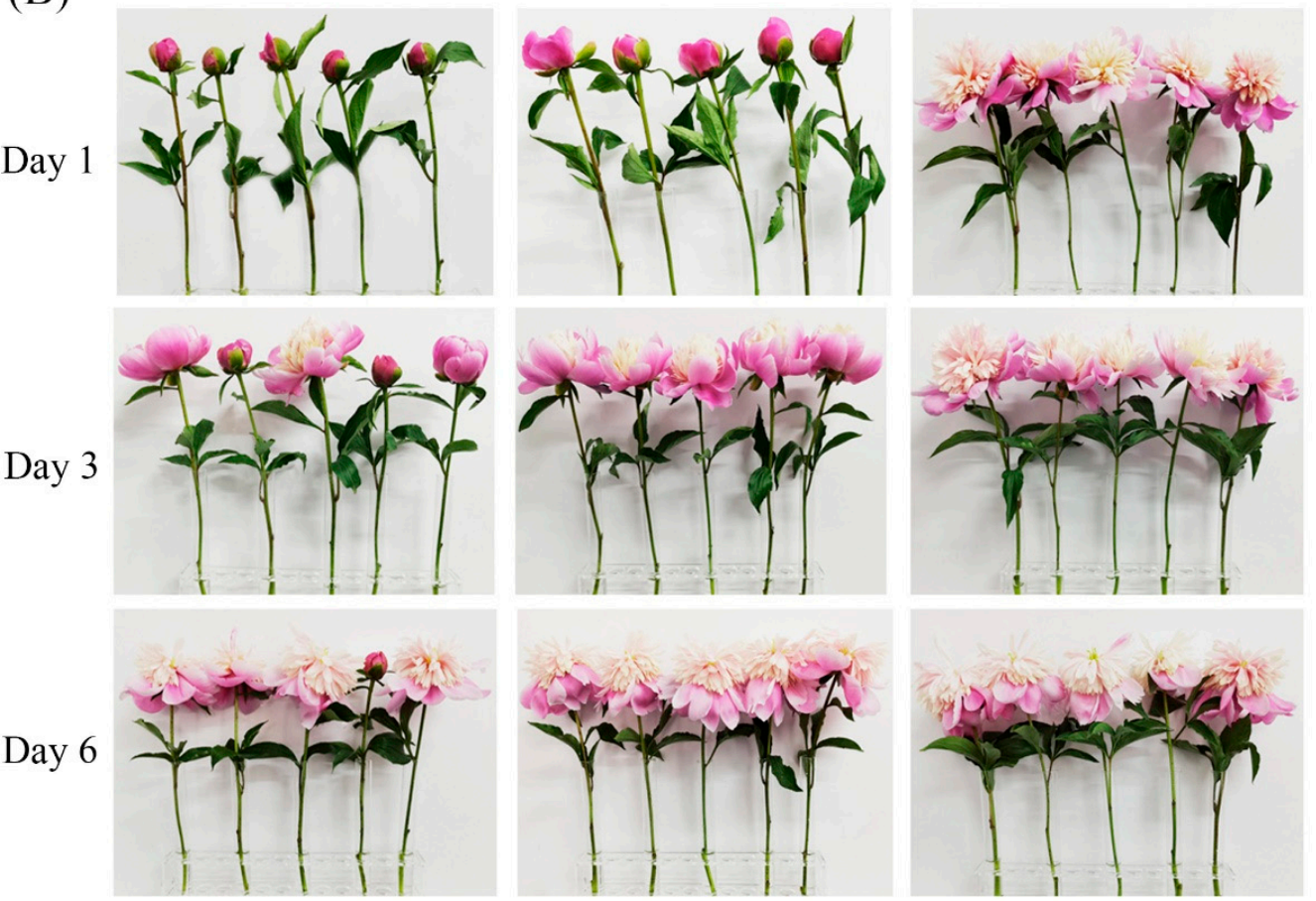

Figure 3. Flower morphological changing and physiological characteristics of in different harvest stages of "unfold-petal type" cut P. lactiflora. (A) The appearance of flowering changes of 'Qihua Lushuang' in three harvesting stages on the first, third and sixth vase day. (B) The appearance of flowering morphology changes of 'Lian Tai' in three harvesting stages on the first, third, and sixth vase day.

Both kinds of cut flowers reached their best flowering state on the third day after harvesting and were fully open. On the sixth day, some flowers began to wilt, and petals began to shrivel (Figure 3). The maximum flower diameter of the cut flowers collected in CC and SB during bottle insertion was $12-13 \mathrm{~cm}$, which was larger than that of the 
cut flowers collected in the TB stage by 9-10 cm (Figure 4A,C). The change rate of fresh weight of the cut flowers collected in CC and TB stage decreased later and slower than that collected in the SB stage (Figure 4B,D).

(A) $\rightarrow \mathrm{TB} \leadsto-\mathrm{CC} \leadsto \mathrm{SB}$
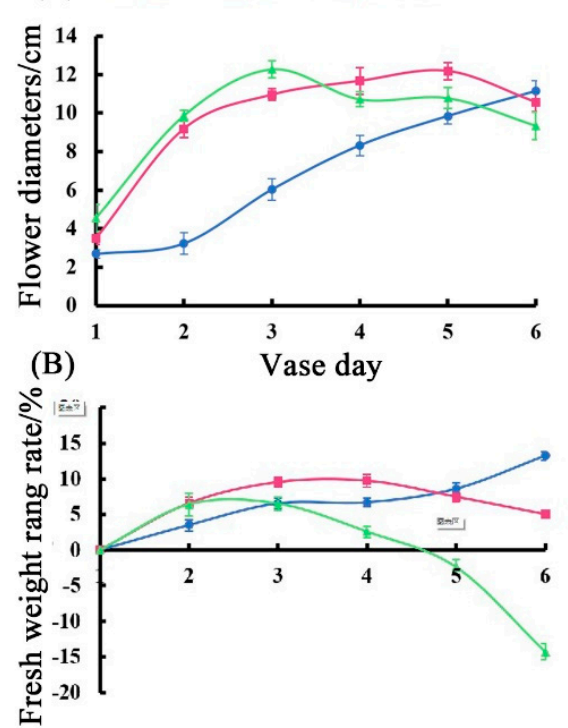

Vase day
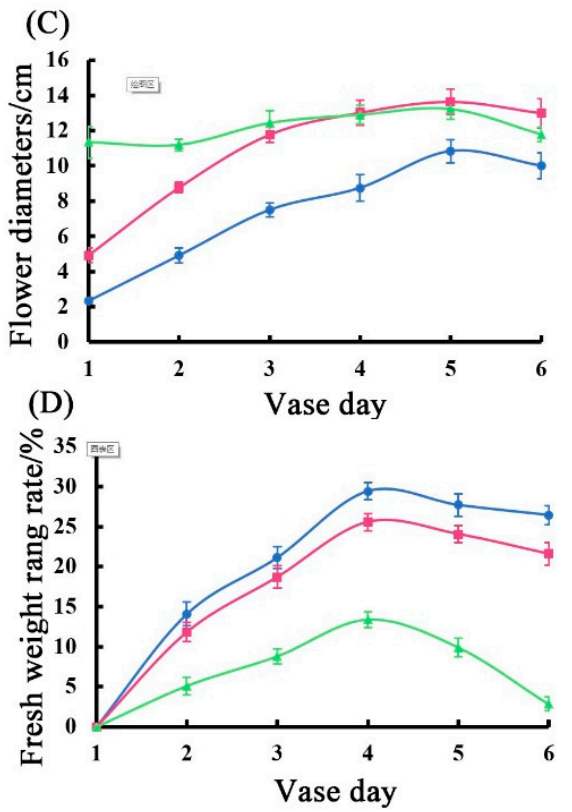

Figure 4. Physiological characteristics of in different harvest stages of "unfold-petal type" cut P. lactiflora. $(\mathbf{A}, \mathbf{C})$ Flower diameter change and fresh weight change rate of 'Qihua Lushuang' in three harvesting stages during bottling. (B,D) Flower diameter change and fresh weight change rate of 'Lian Tai' in three harvesting stages during bottling. TB, tight-bud; CC, changing-color; SB, soft-bud. Values are expressed as the mean \pm SD of three analyses. The vertical bar represents the standard deviation of the mean.

\subsection{The Best Pre-Treatment and Storage Method for Cut P. lactiflora}

According to the bottle insertion test after 30 days of CS, all cut flowers can bloom normally, and the flower flowering rate after 8-HQ and NS pre-treatment was higher than that of the control, and the vase life is up to about 6 days with no significant difference (Table 3). The flower diameter of cut flowers after three pre-treatments was slightly lower than the zero point of refrigeration. However, among them, the flower diameter of 8-HQ treatment was larger than that of deionized water and NS treatment, and the rate of decline was slowest. Besides, the change rate of fresh weight of cut flowers decreased later and at a slower rate after pre-treatment (Figure 5). According to the bottle insertion experiment after 30 days of $\mathrm{CS}+\mathrm{LO}$, the cut peony flowers pre-treated with 8-HQ and NS can bloom normally, the flower diameter was slightly higher than the storage zero, and the vase life can reach 5-6 days, and there was no significant difference, but the cut flowers treated with ionic water cannot bloom normally (Table 3). Moreover, the diameter of cut flowers pre-treated with $8-\mathrm{HQ}$ was larger than that pre-treated with NS, the change rate of fresh weight decreased later and slower, and the treatment effect was better. In addition, the flower diameter of cut flowers after CS + LO was higher than that after CS, and the change rate of fresh weight decreased more slowly (Figure 5). Besides, compared with the two storage methods under the same pre-treatment, the flowering rate of cut flowers was similar, but there was a significant difference in vase life (Table 3). 
Table 3. Flowering rate and vase life of cut flowers under 8-HQ and NS pre-treatment and CS and CS + LO storage.

\begin{tabular}{cccc}
\hline Pre-Treatment Mode & Storage Way & Flowering Rate (\%) & Vase Life (Days) \\
\hline & CS (Cold storage) & 60 & $5.5 \pm 0.15^{\mathrm{a}}$ \\
Deionized water & CS + LO (Cold storage + Low oxygen) & 0 & $0^{\mathrm{b}}$ \\
8-HQ & CS (Cold storage) & 80 & $5.6 \pm 0.12^{\mathrm{a}}$ \\
NS & CS + LO (Cold storage + Low oxygen) & 80 & $5.7 \pm 0.18^{\mathrm{b}}$ \\
& CS (Cold storage) & 85 & $5.6 \pm 0.11^{\mathrm{a}}$ \\
\hline
\end{tabular}

Notes: Means followed by the different lower-case letter have a significant difference at $\alpha=0.05$ (Duncan's test).

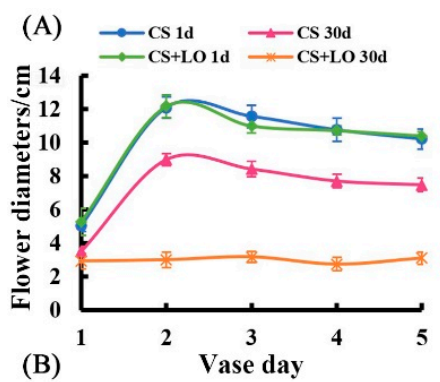

(C)
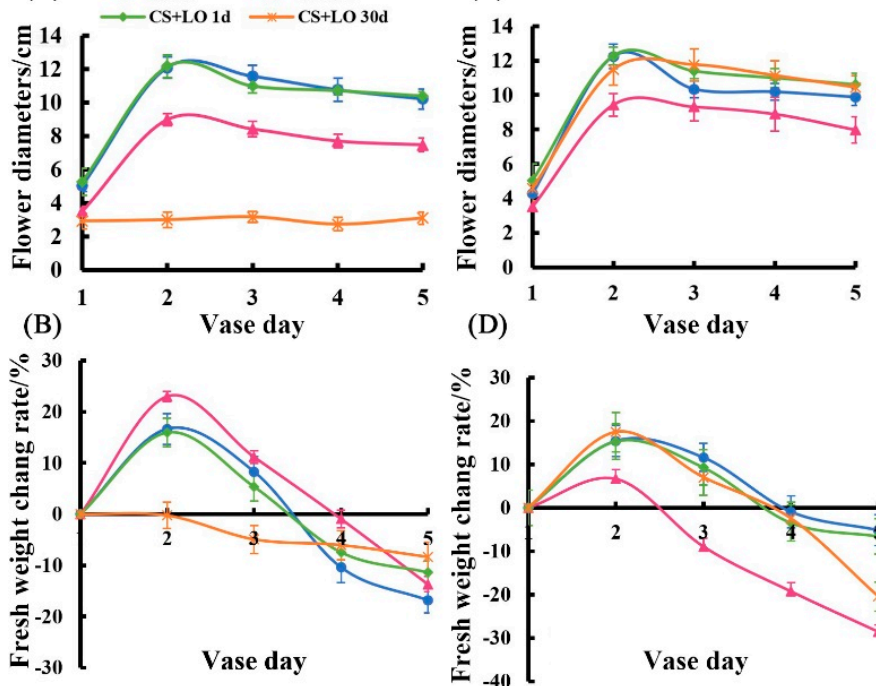

(D)

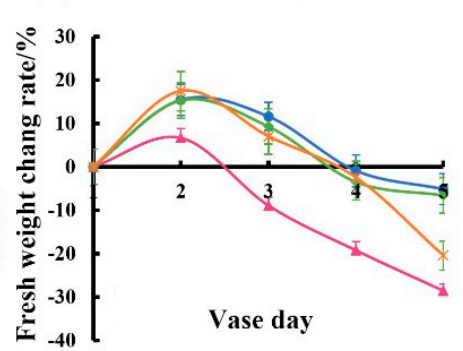

(E)
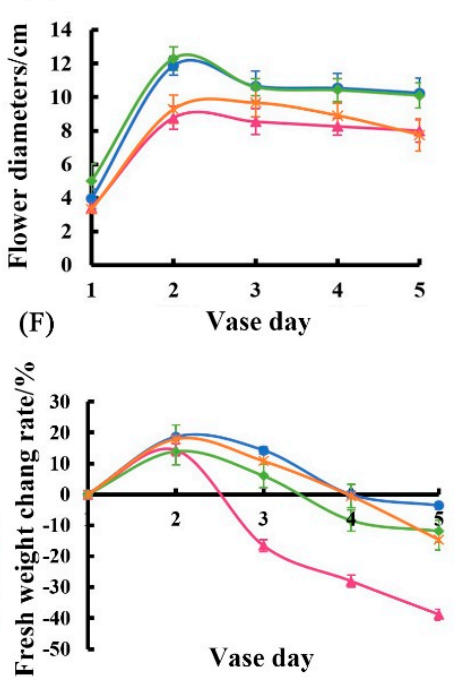

Figure 5. Flower diameter and the change rates of fresh weight of cut $P$. lactiflora in the vase after pre-treating and storage. (A,B) Flower diameter change and fresh weight change rate of cut flowers without pre-treatment during vase insertion on day 1 and day 30. (C,D) Flower diameter change and fresh weight change rate of cut flowers pre-treated by 8-HQ during vase insertion on day 1 and day 30. (E,F) Flower diameter change and fresh weight change rate of cut flowers pre-treated by NS during vase insertion on day 1 and day 30. CS, Cold storage; CS + LO, Cold storage + Low oxygen. Values are expressed as the mean $\pm \mathrm{SD}$ of three analyses. The vertical bar represents the standard deviation of the mean.

The activities of four related protective enzymes decreased after 30 days of storage in the two storage methods, but the enzyme activity of cut flowers under CS + LO was higher than that under CS. Moreover, the enzyme activity of cut flowers after 8-HQ and NS pre-treatment decreased slower than that after ionic water treatment (Figure 6).

In general, the bottle inserting effect of cut flowers pre-treated before storage was better than that of the control, and the effect of the two pre-treatment solutions was better than that of CK. The fresh-keeping effect of cut flowers treated with pre-treatment solution 8-HQ under CS + LO was better than that under CS, and the preservation effect of cut flowers treated with NS under CS was better than that under CS + LO. 


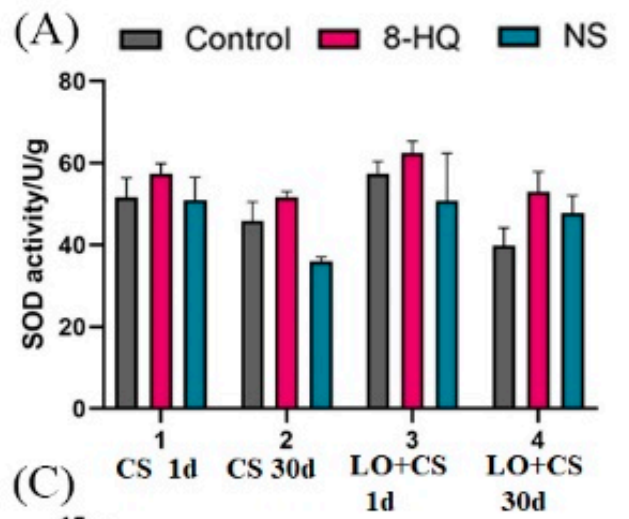

(B)
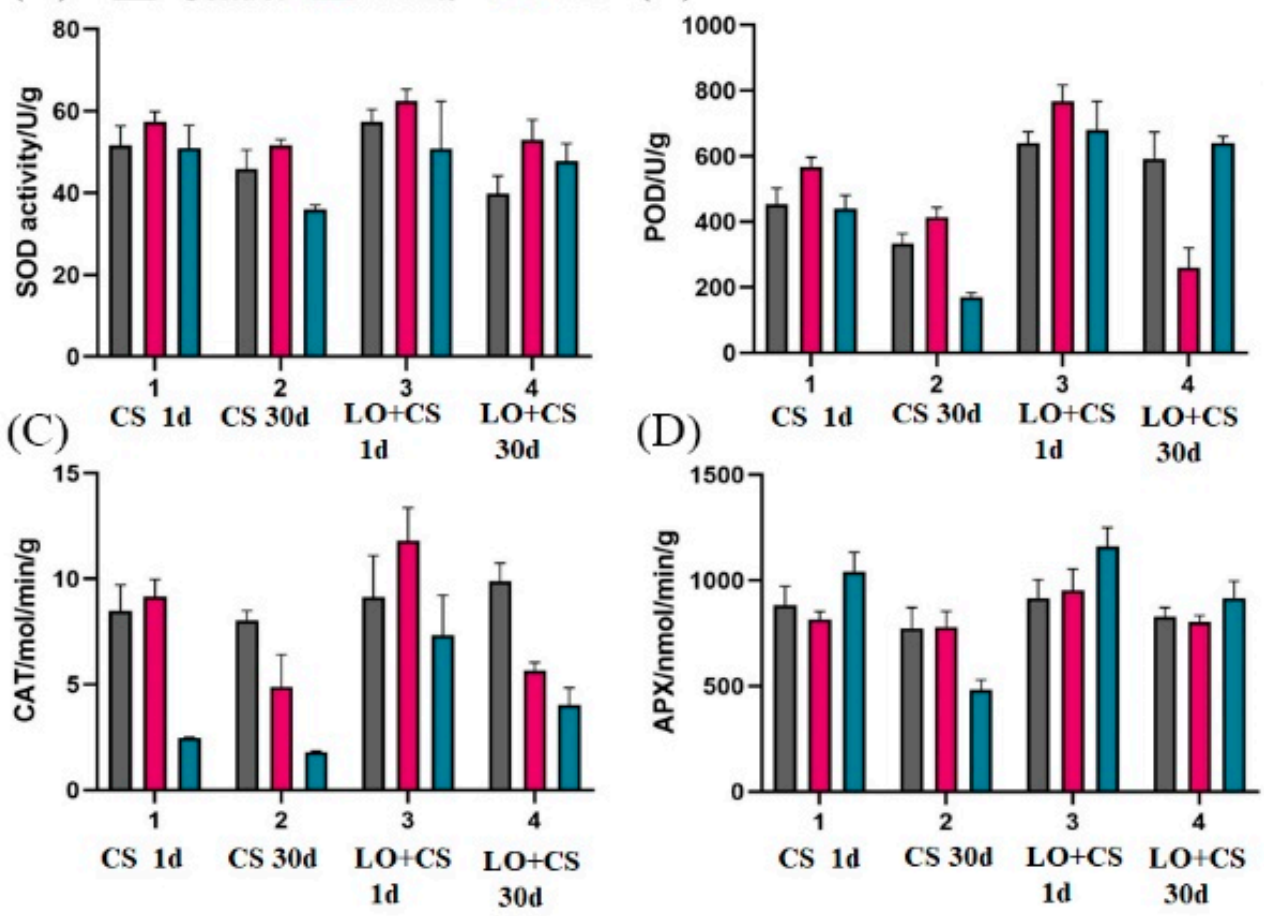

Figure 6. The protective enzyme activities of cut flowers on day 1 and day 30 after two pre-treatment solutions and storage methods. (A) SOD activity; (B) POD activity; (C) CAT activity; (D) APX activity. Values are expressed as the mean \pm SD of three analyses. The vertical bar represents the standard deviation of the means.

\subsection{The Best Carbon Source Fresh-Keeping Solution for Cut P. lactiflora}

The fresh-keeping solution treatment can promote the flowering of cut flowers, significantly prolong the vase life by 1-2 days and the flowering period by about four days, thus significantly improving the ornamental value of cut $P$. lactiflora (Table 4). On the third day of the treatment, the cut flowers entered the best opening state, and the opening effect of cut flowers bottled in the solution containing glucose was the best. On the sixth day, the cut flowers entered the decay stage except the ones added with solution containing trehalose. The cut flowers in the fresh-keeping solution containing trehalose reached their peak flowering time late, and the flowering time was the longest (Figure 7).

Table 4. Vase life and full bloom days of cut flowers in a fresh-keeping solution containing different carbon sources.

\begin{tabular}{ccc}
\hline Carbon Sources & Vase Life (Days) & Full Bloom (Days) \\
\hline CK & $6.2 \pm 0.14^{\mathrm{a}}$ & $3.3 \pm 0.12^{\mathrm{a}}$ \\
Mock & $6.5 \pm 0.10^{\mathrm{b}}$ & $3.6 \pm 0.07^{\mathrm{b}}$ \\
Mannitol & $6.3 \pm 0.08^{\mathrm{a}}$ & $3.8 \pm 0.11^{\mathrm{c}}$ \\
Glucose & $7.6 \pm 0.12^{\mathrm{c}}$ & $4 \pm 0.04^{\mathrm{d}}$ \\
Sucrose & $8 \pm 0.15^{\mathrm{d}}$ & $4.3 \pm 0.08^{\mathrm{e}}$ \\
Trehalose & $8.5 \pm 0.09^{\mathrm{e}}$ & $4.6 \pm 0.1^{\mathrm{f}}$ \\
\hline
\end{tabular}

Note: Means followed by the different lower-case letters have a significant difference at $\alpha=0.05$ (Duncan's test). 


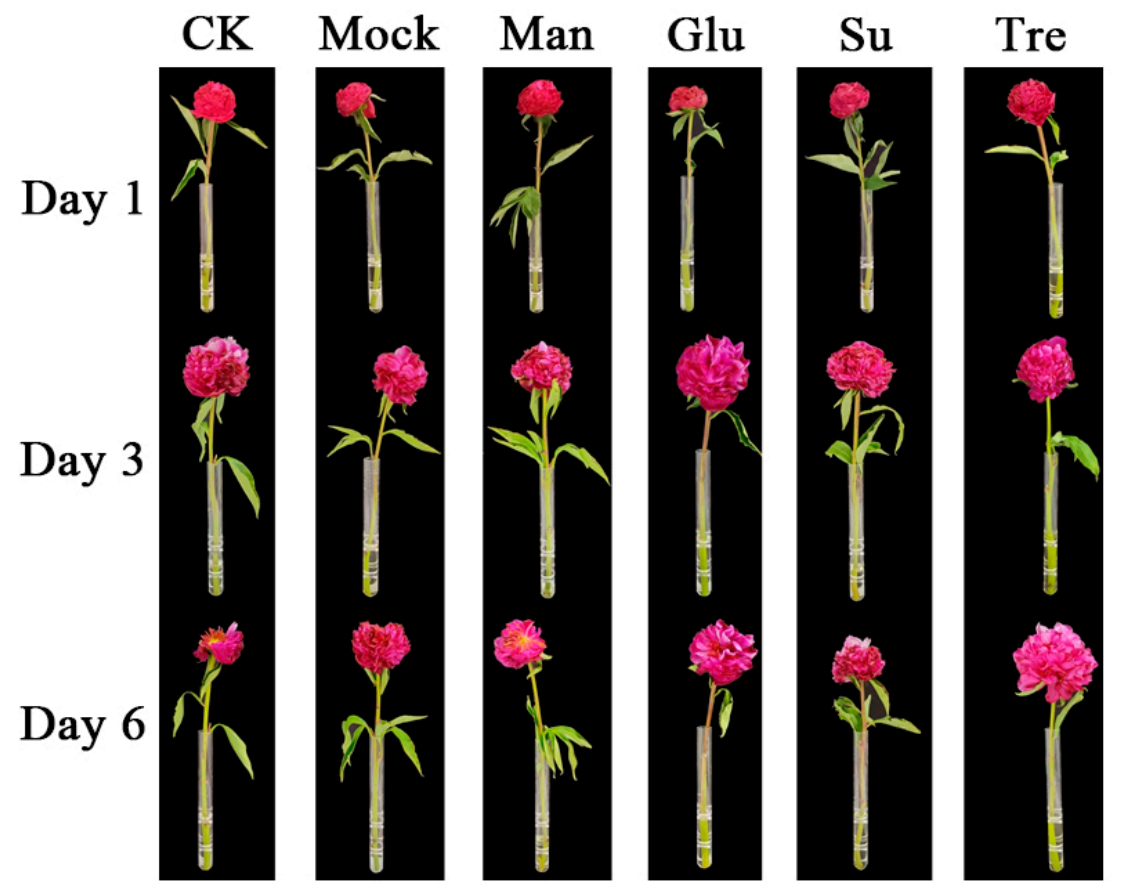

Figure 7. The appearance of flowering morphological changes of cut P. lactiflora in a fresh-keeping solution containing different carbon sources.

Glucose, sucrose, and trehalose treatment can significantly increase the flower diameter, but the cut flowers treated with glucose reached the maximum flower diameter earlier and higher than the other three treatments, and the preservation effect was the best. Trehalose reached the maximum flower diameter on the sixth day in the late opening stage and prolonged the full flowering period. The change rate of fresh weight of cut flowers treated with three sugars began to decline later than that of the control. The fresh-keeping effect of mannitol was not obvious (Figure 8).

(A)

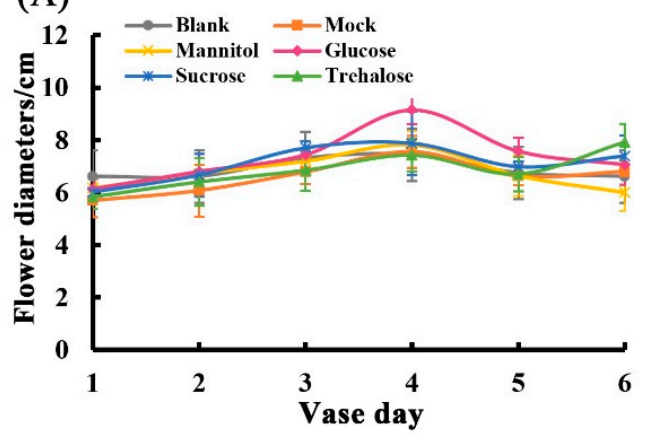

(B)

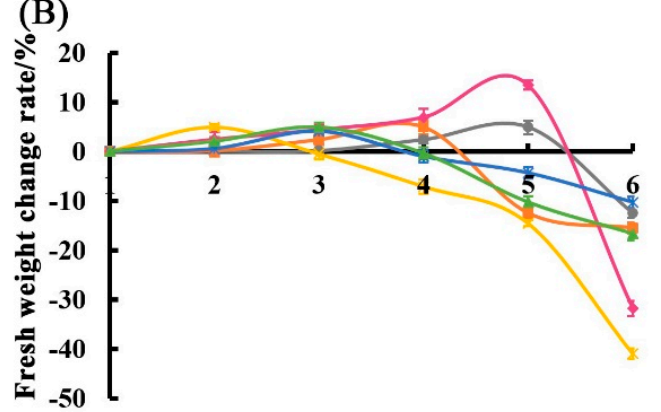

Vase day

Figure 8. Flower diameter and the change rate of fresh weight of cut P. lactiflora in a fresh-keeping solution containing different carbon sources. (A) The flower diameter of 'Hong Feng' cut flowers changed in different holding fluids. (B) The fresh weight change rate of 'Hong Feng' cut flowers changed in different holding fluids. Values are expressed as the mean $\pm \mathrm{SD}$ of three analyses. The vertical bar represents the standard deviation of the mean.

\section{Discussion}

Proper harvesting is the key to keeping fresh cut flowers after harvest. There are many flower types of Paeonia lactiflora, and the opening effect of different varieties harvested at the same level is very different [30]. Our results on the harvest stage, which cut flowers harvested at the TB stage can bloom as normally as those harvested at CC, UT, SB stage 
are consistent with the study of Hill et al., which described the optimum harvest stage for 25 foreign peony varieties. Research shows that the larger buds can produce the larger flowers, and the larger buds that are softer or more open also produce the larger flowers [6]. Differently, Eason et al. showed that cut P. lactiflora cultivar 'Festiva Maxima,' the buds harvested at the immature stage has a greater open vase life than those harvested at the more mature stage [31]. Our study found that cut P. lactiflora flowers harvested at the UT stage and CC stage had a longer vase life than those harvested at the SB stage. However, the cut flowers collected in the TB stage had shorter vase life than those collected in the UT, CC, SB stage, which may be caused by the difference of peony varieties. The results showed that the cut flowers collected in the TB stage had a smaller diameter than those collected in the UT, CC, SB stage, which was similar to H.J. Elgar et al., which considered the earlier the cut Leucocoryne coquimbensis flowers were harvested, the smaller and lighter the flowers were, and the shorter the vase life was [32]. Nevertheless, this was different from Yong kweon Yoo et al., which pointed out that the fresh weight and diameter of the cut flowers harvested at flowering stage 1 or 2 were slightly lower than those harvested at flowering stage 6 , but the vase life was 5.2-5.5 days longer [33]. The possible reason was that the physiological characteristics of different species of flowers at the same harvest stage were different.

Cold storage is often used in the cut peony industry and can extend the sales cycle by more than 20 days. It has been reported that the optimal temperature for storing cut peony is $2-3^{\circ} \mathrm{C}$ [34]. Cold storage is divided into dry storage (DS) and wet storage (WS), delaying aging, prolonging life, and reducing the harm of bacteria to flower branches [35]. DS is commonly used for long-time storage [36]. In our work, after a long storage period, cut flowers with hypoxic refrigeration still had a high flowering rate, and there was no significant difference in vase life compared with normal cut flower life. The reason may be that the low oxygen technologies slow ethylene production and accumulation, respiratory metabolism, and tissue decomposition during ripening [37,38]. For instance, Kawhena et al. and Mditshwa et al. demonstrated that the reduction of superficial scald development on 'Granny Smith' apples can be caused by low oxygen storage technology [37,39]. Similarly, Mditshwa et al. showed that repeated hypoxic techniques can maintain the green color of 'Granny Smith' apples during cold storage. Thus, it can be speculated that the use of hypoxic storage can preserve the color and ornamental value of cut flowers [40].

The most common post-harvest problem in cut flowers is vascular blockage. The problem can be caused by an air embolism or bacterial growth [41]. Another cause of vascular obstruction is the plant's response to cutting, with certain enzymes stimulated during cutting and sent to the cutting area to block it [42]. Our study found that the P. lactiflora cut flowers stored after 8-HQ and NS pre-treatment could bloom normally, the flower diameter was slightly higher than the storage zero, and the vase life could reach 5-6 days as normal, while the control cut flowers could not bloom normally. It is speculated that $8-\mathrm{HQ}$ and NS as fungicides may not only prevent vascular obstruction caused by microorganisms, but also prevent blockage caused by plants themselves, thus improving the water absorption rate of cut flowers [43].

The senescence and loss of ornamental value of cut flowers are related to the production of reactive oxygen species (ROS) [44]. One of them is hydrogen peroxide, which can induce oxidative stress and lead to senescence by degrading proteins, lipids, and nucleic acids. Plants have well-defined antioxidant defenses that mop up harmful free radicals [45]. The antioxidant protection system includes ascorbic acid, $\alpha$-tocopherol, glutathione, phenolic compounds, and flavonoids, as well as a series of enzyme systems, including catalase (CAT), superoxide dismutase (SOD), peroxidase (POD) and ascorbate peroxidase (APX) [46]. However, there are few studies on the effect of storage on antioxidant enzyme activity. In our experiment, the activity levels of all protective enzymes increased first and then decreased during storage. The flower protective enzyme activity after the treatment with fungicides was higher than that of the control group and decreased at a slower rate. The protective enzyme activity of cut flowers after hypoxia refrigeration 
was higher than that of ordinary refrigeration, which may indicate that bactericides and hypoxia technology can improve the fresh-keeping value of cut P. lactiflora through better removal of hydrogen peroxide.

The quality of cut flowers can be maintained, and the vase life can be extended by adding sugar such as sucrose, glucose as carbon sources to the fresh-keeping solution, which is related to improving the water relationship and increasing the available energy for flower tissue respiration $[47,48]$. For instance, in cut roses, sucrose treatment can improve the vase quality by accelerating the expansion of petal cells and significantly increasing the concentration of glucose and fructose in petals $[49,50]$. There are also reports that sugar can improve the quality of cut flowers by affecting the hormone balance of flower tissues and delaying the degradation of mitochondria in senescent petals [51,52]. In our study, glucose, sucrose, and trehalose treatments significantly increased flower diameter, slowed down the decline rate of fresh weight, and extended the flowering period. Based on these results, we believe that the ability of sucrose to improve the quality of cut peony vases involves the process of improving the water balance of internal tissues. We did not measure ethylene production, but according to the study, which glucose in bottle placement solution can significantly reduce the production of endogenous ethylene in peony, protecting the cut peony from ethylene-induced senescence [53-55], we can speculate that glucose may improve the vase quality of cut peony by reducing ethylene sensitivity. Our research also found that trehalose can delay the flowering of cut peony, which may be because trehalose can maintain the activity of petal cells and play a role in changing the metabolism of elongating cells and reducing the membrane conductivity $[56,57]$.

\section{Conclusions}

The optimal harvest time of different types of cut herbaceous peony flowers is different. We first found that the "Open-top type" and "Loose-petal type" Paeonia Lactiflora had the highest flowering rate, the best flowering form, the longest vase life, and the best ornamental value in the soft-bud (SB) stage and changing color (CC) stage, respectively. Meanwhile, after harvest, the effect of cold storage after pre-treatment is better than control. After 8-HQ and NS pre-treatment, the flowering rate and vase life of cut flowers were increased, and the ornamental effect was better. Low oxygen refrigeration technology improves the storage value and vase ornamental of cut flowers by slowing down the reduction of related protective enzyme activities in the later stage of storage. What's more, after treatment with a fresh-keeping solution containing glucose, sucrose, and trehalose, the flower diameter of cut P. lactiflora flowers increased, and the flowering period prolonged. The effect of glucose increasing the flower diameter was the most obvious. Trehalose could delay flowering and prolong the full flowering period. In a word, our experimental results provide data for better establishing a set of fresh-keeping systems of cut P. lactiflora flowers and provide a reference for promoting the international development of the cut herbaceous peony flower industry.

Author Contributions: Conceptualization, J.S.; data curation, H.G.; formal analysis, J.S.; methodology, J.S. and H.G.; project administration, J.S. and J.T.; resources, H.G.; software, H.G.; validation, J.T.; visualization, J.T.; writing—original draft, H.G.; writing-review and editing, H.G. All authors have read and agreed to the published version of the manuscript.

Funding: This research was funded by Modern Agricultural Industrial Technology System in Jiangsu Province (JATS [2020]436), Qing Lan Project of Yangzhou University, Research on the key technologies of the exploitation and uti-lization of the characteristic flower resources based on Leisure Agriculture (CX (20)2030), Long-term scientific research base for conservation and innovative utilization of Peony germplasm resources in Jiangsu Province(LYKJ[2021]01), Agricultural Science \& Technology Independent Innovation Fund of Jiangsu Province (CX(20)3186).

Institutional Review Board Statement: Not applicable.

Informed Consent Statement: Not applicable. 
Data Availability Statement: The data underlying this article are available in the article.

Acknowledgments: This research was funded by Modern Agricultural Industrial Technology System in Jiangsu Province (JATS [2020]436), Qing Lan Project of Yangzhou University, Research on the key technologies of the exploitation and uti-lization of the characteristic flower resources based on Leisure Agriculture (CX (20)2030), Long-term scientific research base for conservation and innovative utilization of Peony germplasm resources in Jiangsu Province(LYKJ[2021]01), Agricultural Science \& Technology Independent Innovation Fund of Jiangsu Province (CX(20)3186).

Conflicts of Interest: No potential conflict of interest was reported by the authors.

\section{References}

1. Xue, J.; Huang, Z.; Wang, S.; Xue, Y.; Ren, X.; Zeng, X.; Zhang, X. Dry storage improves the vase quality of cut peony by increasing water uptake efficiency through aquaporins regulation. Plant Physiol. Biochem. 2020, 148, 63-69. [CrossRef]

2. Cheng, F.; Gao, S.; Yu, X. Stage division and morphological types of peony bud maturation and flowering. J. Hortic. 2009, 36, 611-613. (In Chinese) [CrossRef]

3. Gao, S. Study on Postharvest Technology of Cut Peony Flowers; Beijing Forestry University: Beijing, China, 2006. (In Chinese)

4. Varu, D.K.; Barad, A.V. Effect of stem length and stage of harvest on vase-life of cut flowers in tuberose (Polianthes tuberosa L.) cv. Double. J. Hortic. Sci. 2010, 5, 42-47.

5. Walton, E.F.; Boldingh, H.L.; McLaren, G.F.; Williams, M.H.; Jackman, R. The dynamics of starch and sugar utilisation in cut peony (Paeonia lactiflora Pall.) stems during storage and vase life. Postharvest Biol. Technol. 2010, 58, 142-146. [CrossRef]

6. Gast, K.; McLaren, J.; Kampjes, R. Identification of bud maturity indicators for fresh-cut peony flowers. Acta Hortic. 2001, 543, 317-325. [CrossRef]

7. Gao, S.; Wei, C.; Wang, Y.; Lu, M.; Fan, B. Effects of harvest stage on ornamental quality of cut flowers of herbaceous peony (Paeonia lactiflora Pall.). J. Henan Agric. Sci. 2013, 42, 115-121. (In Chinese)

8. Jahnke, N.J.; Dole, J.M.; Bergmann, B.A.; Ma, G.; Perkins-Veazie, P. Extending Cut Paeonia Lactiflora Pall. Storage Duration Using Sub-Zero Storage Temperatures. Agronomy 2020, 10, 1694. [CrossRef]

9. Teixeira da Silva, J.A. The cut flower: Postharvest considerations. J. Biol. Sci. 2003, 3, 406-442.

10. Skutnik, E.; Rabiza-Świder, J.; Jedrzejuk, A.; Łukaszewska, A. The Effect of the Long-Term Cold Storage and Preservatives on Senescence of Cut Herbaceous Peony Flowers. Agronomy 2020, 10, 1631. [CrossRef]

11. Xue, J.; Tang, Y.; Wang, S.; Xue, Y.; Liu, X.; Zhang, X. Evaluation of dry and wet storage on vase quality of cut peony based on the regulation of starch and sucrose metabolism. Postharvest Biol. Technol. 2019, 155, 11-19. [CrossRef]

12. Łysiak, G.P.; Rutkowski, K.; Walkowiak-Tomczak, D. Effect of Storage Conditions on Storability and Antioxidant Potential of Pears cv. 'Conference'. Agriculture 2021, 11, 545. [CrossRef]

13. Khan, M.R.; Suwanamornlert, P.; Leelaphiwat, P.; Chinsirikul, W.; Chonhenchob, V. Quality and biochemical changes of longan (Dimocarpus longan Lour cv. 'Daw') fruit under different controlled atmosphere conditions. Int. J. Food Sci. Technol. 2017, 52, 2163-2170. [CrossRef]

14. Skutnik, E.; Jędrzejuk, A.; Rabiza-Świder, J.; Rochala-Wojciechowska, J.; Latkowska, M.; Łukaszewska, A. Nano-silver as a novel biocide for control of senescence in garden cosmos. Sci. Rep. 2020, 10, 10274. [CrossRef]

15. Edrisi, B.; Sadrpoor, A.; Saffari, V. Effects of chemicals on vase life of cut carnation (Dianthus caryophyllus L.) 'Delphi' and microorganisms' population in solution. J. Ornam. Plants 2015, 2, 1-11.

16. Kazaz, S.; Dogan, E.; Kılıc, T.; Sahin, E.; Seyhan, S. Influence of holding solutions on vase life of cut hydrangea flowers (Hydrangea macrophylla Thunb.). Fresenius Environ. Bull. 2019, 28, 3554-3559.

17. Lama, B.; Ghosal, M.; Kumar Gupta, S.; Mandal, P. Assessment of different preservative solutions on vase life of cut roses. J. Ornam. Plants 2015, 3, 171-181.

18. Sharifzadeh, K.; Asil, M.H.; Roein, Z.; Sharifzadeh, M. Effect of 8-Hydroxyquinoline Citrate, Sucrose and Peroxidase Inhibitors on Vase Life of Lisianthus (Eustoma grandiflorum L.) Cut Flowers. J. Hortic. Res. 2014, 22, 41-47. [CrossRef]

19. Rai, M.; Yadav, A.; Gade, A. Silver nanoparticles as a new generation of antimicrobials. Biotechnol. Adv. 2009, 27, 76-83. [CrossRef]

20. Hassan, F.A.S.; Ali, E.F.; El-Deeb, B. Improvement of postharvest quality of cut rose cv. "First Red" by biologically synthesized silver nanoparticles. Sci. Hortic. 2014, 179, 340-348. [CrossRef]

21. Safa, Z.; Hashemabadi, D.; Kaviani, B.; Nikchi, N.; Zarchini, M. Studies on quality and vase life of cut Grbera jamesonii cv. 'Balance' flowers by silver nanoparticles and chlorophenol. J. Environ. Biol. 2015, 36, 425-431. [PubMed]

22. Li, H.; Lin, Y.; Liu, C.; Huang, X.; Zhou, H.; He, S. Freshness-preserving effects of nano-silver pre-treatments on cut lily flowers. North. Hortic. 2012, 8, 166-169. (In Chinese)

23. Naing, A.H.; Win, N.M.; Han, J.-S.; Lim, K.B.; Kim, C.K. Role of Nano-silver and the Bacterial Strain Enterobacter cloacae in Increasing Vase Life of Cut Carnation 'Omea'. Front. Plant Sci. 2017, 8, 1590. [CrossRef]

24. Zhao, D.; Cheng, M.; Tang, W.; Liu, D.; Zhou, S.; Meng, J.; Tao, J. Nano-silver modifies the vase life of cut herbaceous peony (Paeonia lactiflora Pall.) flowers. Protoplasma 2018, 255, 1001-1013. [CrossRef]

25. Gómez-Merino, F.C.; Castillo-González, A.M.; Ramírez-Martínez, M.; Trejo-Téllez, L.I. Lanthanum delays senescence and improves postharvest quality in cut tulip (Tulipa gesneriana L.) flowers. Sci. Rep. 2020, 10, 19437. [CrossRef] 
26. Asrar, A.-W.A. Effects of some preservative solutions on vase life and keeping quality of snapdragon (Antirrhinum majus L.) cut flowers. J. Saudi Soc. Agric. Sci. 2012, 11, 29-35. [CrossRef]

27. Kong, L.; Li, F.; Du, R.; Geng, H.; Li, S.; Wang, J. Effects of Different Preservatives on Cut Flower of Luculia pinceana: A Novel Fragrant Ornamental Species. Hortscience 2021, 56, 795-802. [CrossRef]

28. Pun, U.K.; Ichimura, K. Role of Sugars in Senescence and Biosynthesis of Ethylene in Cut Flowers. Jpn. Agric. Res. Q. JARQ 2003, 37, 219-224. [CrossRef]

29. Kondo, M.; Nakajima, T.; Shibuya, K.; Ichimura, K. Comparison of petal senescence between cut and intact carnation flowers using potted plants. Sci. Hortic. 2020, 272, 109564. [CrossRef]

30. Guo, P.; Yu, X. The optimum harvesting maturity grades of introduced herbaceous peonies for cutting flower. Res. Prog. Ornam. Hortic. China 2009, 458-462.

31. Eason, J.; Pinkney, T.; Heyes, J.; Brash, D.; Bycroft, B. Effect of storage temperature and harvest bud maturity on bud opening and vase life of Paeonia lactiflora cultivars. N. Z. J. Crop Hortic. Sci. 2002, 30, 61-67. [CrossRef]

32. Elgar, H.J.; Fulton, T.A.; Walton, E.F. Effect of harvest stage, storage and ethylene on the vase life of Leucocoryne. Postharvest Biol. Technol. 2003, 27, 213-217. [CrossRef]

33. Yoo, Y.K.; Roh, Y.S. Effects of Shipping Temperature and Harvesting Stage on Quality and Vase Life of Cut Flowers in Dendranthema grandiflorum 'Baekma' for Export. Korean J. Hortic. Sci. Technol. 2015, 33, 61-69. [CrossRef]

34. Jahnke, N.J.; Dole, J.M.; Livingston, D.P.; Bergmann, B.A. Impacts of carbohydrate pulses and short-term sub-zero temperatures on vase life and quality of cut Paeonia lactiflora Pall. hybrids. Postharvest Biol. Technol. 2020, 161, 111083. [CrossRef]

35. Shahri, W.; Tahir, I.; Islam, S.T.; Bhat, M.A. Effect of dry and wet storage at cool temperatures on the post-harvest performance of Ranunculus asiaticus L. flowers. Front. Agric. China 2011, 5, 382-387. [CrossRef]

36. Ahmad, I.; Dole, J.M.; Amjad, A.; Ahmad, S. Dry Storage Effects on Postharvest Performance of Selected Cut Flowers. Horttechnology 2012, 22, 463-469. [CrossRef]

37. Kawhena, T.G.; Fawole, O.A.; Opara, U.L. Application of Dynamic Controlled Atmosphere Technologies to Reduce Incidence of Physiological Disorders and Maintain Quality of 'Granny Smith' Apples. Agriculture 2021, 11, 491. [CrossRef]

38. Butkeviciute, A.; Viskelis, J.; Viskelis, P.; Liaudanskas, M.; Janulis, V. Changes in the Biochemical Composition and Physicochemical Properties of Apples Stored in Controlled Atmosphere Conditions. Appl. Sci. 2021, 11, 6215. [CrossRef]

39. Mditshwa, A.; Fawole, O.A.; Vries, F.; van der Merwe, K.; Crouch, E.; Opara, U.L. Repeated application of dynamic controlled atmospheres reduced superficial scald incidence in 'Granny Smith' apples. Sci. Hortic. 2017, 220, 168-175. [CrossRef]

40. Mditshwa, A.; Fawole, O.A.; Opara, U.L. Recent developments on dynamic controlled atmosphere storage of apples-A review. Food Packag. Shelf Life 2018, 16, 59-68. [CrossRef]

41. Davood, H.; Hamideh, B. Comparison Tea Extract, 8-Hydroxy Quinoline Sulfate and Rifampicin on the Vase Life of Cut Chrysanthemum (Denderanthema grandiflorum L. cv. Purple). J. Ornam. Plants 2014, 4, 39-43.

42. Loubaud, M.; van Doorn, W.G. Wound-induced and bacteria-induced xylem blockage in roses, Astilbe, and Viburnum. Postharvest Biol. Technol. 2004, 32, 281-288. [CrossRef]

43. Kim, Y.; Lee, J.S. Changes in bent neck, water balance and vase life of cut rose cultivars as affected by preservative solution. J. Korean Soc. Hortic. Sci. 2002, 43, 201-207.

44. Zou, J.; Zhou, Y.; Cai, X.; Wang, C. Increase in DNA fragmentation and the role of ethylene and reactive oxygen species in petal senescence of Osmanthus fragrans. Postharvest Biol. Technol. 2014, 93, 97-105. [CrossRef]

45. Rogers, H.I. Is there an important role for reactive oxygen species and redox regulation during floral senescence? Plant Cell Environ. 2012, 35, 217-233. [CrossRef]

46. Gill, S.S.; Tuteja, N. Reactive oxygen species and antioxidant machinery in abiotic stress tolerance in crop plants. Plant Physiol. Biochem. 2010, 48, 909-930. [CrossRef]

47. Rabiza-Swider, J.; Skutnik, E.; Jedrzejuk, A.; Łukaszewska, A. Postharvest Treatments Improve Quality of Cut Peony Flowers Agronomy 2020, 10, 1583. [CrossRef]

48. Villanueva, E.; Fujibayashi-Yoshii, N.; Matsuzaki, S.; Yamazaki, K.; Burana, C.; Yamane, K. Effects of Trehalose and Sucrose on the Vase Life and Physiology of Cut Astilbe (Astilbe $\times$ arendsii Arends) Flowers. Hortic. J. 2019, 88, 276-283. [CrossRef]

49. Xue, J.; Tang, Y.; Wang, S.; Yang, R.; Xue, Y.; Wu, C.; Zhang, X. Assessment of vase quality and transcriptional regulation of sucrose transporter and invertase genes in cut peony (Paeonia lactiflora 'Yang Fei Chu Yu') treated by exogenous sucrose. Postharvest Biol. Technol. 2018, 143, 92-101. [CrossRef]

50. Norikoshi, R.; Shibata, T.; Niki, T.; Ichimura, K. Sucrose treatment enlarges petal cell size and increases vacuolar sugar concentrations in cut rose flowers. Postharvest Biol. Technol. 2016, 116, 59-65. [CrossRef]

51. Arrom, L.; Munné-Bosch, S. Sucrose accelerates flower opening and delays senescence through a hormonal effect in cut lily flowers. Plant Sci. 2012, 188-189, 41-47. [CrossRef]

52. Rabiza-Świder, J.; Rochala, J.; Jędrzejuk, A.; Skutnik, E.; Łukaszewska, A. Symptoms of programmed cell death in intact and cut flowers of clematis and the effect of a standard preservative on petal senescence in two cultivars differing in flower longevity. Postharvest Biol. Technol. 2016, 118, 183-192. [CrossRef]

53. Wang, Y.; Zhang, C.; Wang, X.; Wang, W.; Dong, L. Involvement of glucose in the regulation of ethylene biosynthesis and sensitivity in cut Paeonia suffruticosa flowers. Sci. Hortic. 2014, 169, 44-50. [CrossRef] 
54. Zhang, C.; Fu, J.; Wang, Y.; Gao, S.; Du, D.; Wu, F.; Guo, J.; Dong, L. Glucose supply improves petal coloration and anthocyanin biosynthesis in Paeonia suffruticosa 'Luoyang Hong' cut flowers. Postharvest Biol. Technol. 2015, 101, 73-81. [CrossRef]

55. Zhang, C.; Wang, Y.; Fu, J.; Dong, L.; Gao, S.; Du, D. Transcriptomic analysis of cut tree peony with glucose supply using the RNA-Seq technique. Plant Cell Rep. 2013, 33, 111-129. [CrossRef] [PubMed]

56. Otsubo, M.; Iwaya-Inoue, M. Trehalose delays senescence in cut gladiolus spikes. Hortscience 2000, 35, 1107-1110. [CrossRef]

57. Wada, H.; Iwaya-Inoue, M.; Akita, M.; Nonami, H. Hydraulic conductance in tepal growth and extension of vase life with trehalose in cut tulip flowers. J. Am. Soc. Hortic. Sci. 2005, 130, 275-286. [CrossRef] 